\title{
Food Insecurity Associated with Double-Burden of Malnutrition among Women in Reproductive Age in Ciampea Sub-district, Bogor, West Java
}

\author{
Seala Septiani ${ }^{1,2 *}$, Ismi Irfiyanti ${ }^{1,2,4}$, Tran Thi Hai ${ }^{1,2}$, Helda Khusun ${ }^{1}$, Luh Ade Wiradnyani ${ }^{1}$, Aria Kekalih ${ }^{3}$, Paulus Daniel \\ Sahanggamu ${ }^{1,5}$ \\ ${ }^{1}$ Southeast Asian Ministers of Education Organization Regional Center of Food and Nutrition (SEAMEO RECFON), Jl. \\ Utan Kayu Raya No.1A, RW.8, Utan Kayu Utara, Matraman, Jakarta Timur, Jakarta 13120, Indonesia \\ ${ }^{2}$ Department of Nutrition, Faculty of Medicine, Universitas Indonesia, affiliated with Dr. Cipto Mangunkusumo Hospital, \\ Jakarta, Indonesia \\ ${ }^{3}$ Family Medicine Division, Department of Community Medicine, Universitas Indonesia, affiliated with Dr. Cipto \\ Mangunkusumo Hospital, Jakarta, Indonesia \\ ${ }^{4}$ Department of Nutrition, Faculty of Midwifery and Nursing, Megarezky University, Jl. Antang Raya No. 43, Makassar, \\ Indonesia \\ ${ }^{5}$ FHI 360, Infectious Diseases and Health Systems, Jakarta, Indonesia
}

*Corresponding Author:

Seala Septiani

E-mail: septiani.seala@,gmail.com

\begin{abstract}
Double burdens of malnutrition among women have occurred across most developing countries including Indonesia. This study compared the associated factors among overweight and underweight of women in reproductive age (WRA) in rural Ciampea Sub-district, Bogor, West Java. This cross-sectional study surveyed the nutritional status of 575 mothers (16-49 years old) who have under two-years-old children. Nutritional status was assessed by body-mass-index (BMI) and mid-upper arm circumference (MUAC), food security status by US-Food Security Survey Module (US-FSSM), dietary intake by a single 24-H dietary recall. The prevalence of underweight, overweight, and obese among this group were $10 \%, 15.8 \%$, and $34.2 \%$. Food security status was the single factor associated with overweight $(\mathrm{p}=0.026)$. However, after adjustment with other factors, food insecurity with hunger was found to be the highest risk of being underweight (AdjOR=3.95; 95\%CI: 1.46-10.64). Contrarily, it contributed to lower chances of being overweight among WRA (AdjOR=0.40, 95\%CI: 0.21-0.77). In conclusion, food security status in this population associated with both under- and over-nutrition, in addition to other factors such as age and education level of WRA. Ensuring the availability and affordability of nutritious food together with proper nutrition education to rural communities might be worthwhile to improve this condition.
\end{abstract}

Keywords: women in reproductive age (WRA), maternal health, double-burden of malnutrition, food security, rural community.

\begin{abstract}
Abstrak
Beban ganda malnutrisi pada wanita terjadi di sebagian besar negara berkembang, termasuk Indonesia. Penelitian ini membandingkan faktor-faktor yang berhubungan pada wanita usia subur (WUS) dengan status gizi kurang dan lebih di pedesaan Ciampea, Bogor, Jawa Barat. Studi potong lintang ini mensurvei status gizi pada 575 Ibu (usia 16-49 tahun) yang memiliki baduta. Penilaian status gizi menggunakan indeks massa tubuh (IMT) dan lingkar lengan atas (LILA), status ketahanan pangan oleh US-Food Security Survey Module (USFSSM), asupan makanan dengan food recall 24-jam. Prevalensi gizi kurang, lebih, dan obesitas pada kelompok ini adalah 10\%, 15,8\%, dan 34,2\%. Status ketahanan pangan merupakan faktor tunggal yang terkait dengan kelebihan berat badan ( $p=0,026)$. Namun, setelah disesuaikan dengan faktor lain, kerawanan pangan dengan kelaparan ditemukan sebagai risiko tertinggi terjadinya gizi kurang (AdjOR = 3.95; CI 95\%: 1.46-10.64). Sebaliknya, kondisi tersebut berisiko lebih rendah terhadap kejadian gizi lebih pada WUS (AdjOR =0,40, 95\% CI: 0,21-0,77). Kesimpulannya, status ketahanan pangan pada populasi ini berhubungan dengan kejadian ganda malnutrisi, selain faktor lain seperti usia dan tingkat pendidikan. Memastikan ketersediaan dan keterjangkauan pangan bergizi bersama dengan edukasi gizi yang tepat untuk masyarakat pedesaan mungkin bermanfaat untuk memperbaiki kondisi ini.
\end{abstract}

Kata Kunci: wanita usia subur (WUS), kesehatan ibu, beban ganda malnutrisi, ketahanan pangan, penduduk pedesaan. 


\section{Introduction}

Half of all Sustainable Development Goals (SDGs) are depending on women's health status. Despite efforts undertaken, the achievement of health goals seems unsatisfactory. Many factors contributed to the low achievement of targets on maternal and infant mortality. It has been shown that maternal nutritional status before, during, and after pregnancy contributes a great deal to those targets (14). Some evidence from developing countries indicates that malnourished individuals, that is, overweight or underweight women are more likely to give preterm birth, have increased mortality rates, as well as increased risk of illness $(17,13)$. Causes of both under- and over-nutrition are complex and multifactorial. Previous studies found that household food diversity, household food insecurity, marital status, education level, and socioeconomic status were associated with nutritional status, both in underweight and overweight women of reproductive age $(1,2)$.

Indonesia was suspected to be laden on a double burden of malnutrition problem, including in rural areas since the country has shifted from low-income to low-middle-income (16). Women of reproductive age (WRA) who are having under-two years-old children are one of the vulnerable groups of high priority. Those who suffer from malnutrition, especially chronic energy deficiency (CED) will give a snowball burden to themselves as well as another generation in the whole life cycle. In Bogor district, the prevalence of underweight among women aged over 18 years-old is $13.5 \%$ while overweight is $15.8 \%$ (10). Therefore, we conducted this study to get baseline information on the current nutrition situation and its associated factors in the at-risk population of the rural community.

\section{Methods}

This cross-sectional study was conducted in May 2015. The total sample was 575 mothers aged 16-49 with undertwo years-old children using purposive random sampling from all 13 villages in Ciampea Sub-district, West Java. The random selection was using NutriENA. However, the respondents' age range was from 16 to 44 years-old. We interviewed each subject for 40-50 minutes either in their home or in a designated place. Following the interview, we assessed respondents' nutritional status on the same day.

We developed a structured questionnaire to assess demographic data, wealth index, food security status, dietary assessment, and nutritional knowledge. Validated of US-Food Security Survey Module (US-FSSM) was used to determine household food security status. Dietary intake data, particularly energy, and protein intake, were estimated using a single 24-hour dietary recall. To assure consistent assessment of portion size, type and amount of food, all enumerators were helped by standardized food photographs from Total Diet Survey of Indonesia, Litbangkes RI (11), with intensive training before the data collection. For nutritional knowledge, eight questions about nutritional knowledge were related to the balanced diet were constructed based on the recommendation of the Ministry of Health of Indonesia (12). The questionnaire was pilot tested in a similar population to ensure its applicability in collecting the required data. Further, bodyweight was assessed using the CSECA weighting scale while height was measured by a validated length board. Mid-upper arm circumference (MUAC) was measured using a flexible and nonstretchable CSECA tape. The weighing scale was calibrated before data collection.

Based on Asian cut-off points (15), we 
divided the women into two main groups: underweight or BMI $<18.5$ and overweight or $\mathrm{BMI} \geq 23$. The chosen indicators for multivariate analysis were variables related to nutritional outcomes based on bivariate analysis ( $p$-value $\leq$ 0.25 ). Due to data from 39 low- and middle-income countries concluded that education and wealth status influenced the significantly nutritional status of populations (6), this study considered these variables in the logistic regression model.

\section{Results}

A total number of 575 women of reproductive age (WRA) were included in the analysis. The median age was 29 (1644 ) years-old. About $42.6 \%$ of them had a low educational level, having graduated from elementary school only. There were only $11.3 \%$ working which most of them were having a family planning program. Interestingly, we found $34.2 \%$ were obese while underweight still occurred. Of the $10 \%$ of underweight women, $69 \%$ identified as having chronic energy deficiency (CED). The median intake of energy was $1654.2(130-5625) \mathrm{kcal}$ hand protein was 53 (2-526) grams. We found more than half of WRA $(59.5 \%)$ had a medium diversity of food intake or consumed 3-4 out of 9 food groups based on FAO (2010), while only $16.9 \%$ of them had ideal food diversity consumption (3). Over $50 \%$ were in food insecurity condition, mostly with no hunger (41\%). The detailed information regarding the characteristics of the respondents could be seen in Table 1.

Bivariate analysis (Table 2) found that food security status was significantly associated with overweight $(\mathrm{p}=0.026)$. More than half of the highest prevalence of underweight occurred among those with food insecurity with hunger (17.1\%).
On the other hand, more than half of overweight WRA were in food insecurity without hunger status $(52.3 \%)$. Contrary to the basic theory, education level significantly associated with underweight $(\mathrm{p}=.012)$ that higher education level more likely to be underweight. A similar phenomenon tended to occur on the association between nutritional knowledge with overweight ( $\mathrm{p}=.052)$.

Although statistically insignificant, it showed that the overweight prevalence tends to be higher among subjects with excess energy intake. Furthermore, there was a pattern that the lower the wealth tertile, the higher prevalence of underweight. In contrast, the higher the wealth tertile, the higher prevalence of overweight.

Further, we conducted a multivariate analysis for underweight and overweight separately. All variables which have pvalue $<0.25$ in the bivariate analysis were included in the logistic regression model. Table 3 shows the unadjusted and adjusted odds ratio for the association between food security and education of women of reproductive age with underweight. After adjustment with all other factors, four indicators associated with underweight; food insecure with hunger $(\mathrm{AdjOR}=3.95 ; 95 \% \mathrm{CI}$ : $1.46-$ 10.64), low education $(\mathrm{AdjOR}=0.22$; $95 \% \mathrm{CI}: 0.10-0.52$ ), age groups of $16-18$ and 19-29 years-old with $\mathrm{AdjOR}=10.05$ (95\%CI: $1.48-68.22$ ) and $\mathrm{AdjOR}=3.34$ (95\%CI: $1.67-6.70)$, respectively. It means the younger the age of WRA, the higher the risk of being underweight. We differentiate those who were still 16-18 years-old as adolescent rather than an adult.

Previously, the bivariate analysis showed that food security status was the single factor associated with overweight (Table 3). However, on the adjusted model (Table 4), those who experienced food insecurity with hunger 
were 0.40 less likely to be overweight (95\% CI: $0.21-0.77)$ than those who were food secure, while those being food secure at risk were also 0.57 times less likely to be overweight $(95 \% \mathrm{CI}: 0.34-1.00)$ than those who were food secure. This predictor's model could explain 14.1\% (R2 0.141 ) of the causal relationship with underweight and 8.6\% (R2 0.086) with overweight.

\section{Discussion}

Long time, we consider those urban people with good access to food are the only group with a high risk of overweight and obesity, while those in the rural area are only at risk of underweight. This study made an important mark on the association between food security status and both under- and over-nutrition, in different ways. From the bivariate analysis, we found that food security status is associated with the nutritional status of WRA ( $p=0.026)$. Interestingly, this data shows that not only those with food-secure status strongly tend to be overweight but also those with food insecurity, but, without hunger. Further after adjustment, there was an additional indication that certain stages of food insecurity might be a protective factor of being overweight, but roughly, the more food secure, the higher the prevalence of overweight. On the other hand, the higher level of food insecurity - with hungerwas one of the risk factors of being underweight. The adjusted analysis showed that those who experienced food insecurity with hunger were at almost four times higher risk of being underweight. Hunger and poverty are having a close relationship with under-nutrition (7). The wealth index data also indicated a similar theory (Table 2).
The divergent results showed food insecurity without hunger had a low prevalence of underweight. Whereas the high prevalence of overweight might also be explained by the escalation prevalence of overweight on this particular group of WRA. Besides, insecurity in food availability, but not yet hunger, might lead to a bad quality diet. It can be seen in the pattern of energy intake and dietary diversity of this population (Tables 1 and 2 ). Association between food insecurity and high BMI has been an issue in developed countries (9) and a few developing countries (4). Low-income families chose energy-dense food with poor nutritional value than nutritious food (such as vegetables, fruit). It would lead to overweight and obesity (18). Focused intervention in this population could be addressed to ensure nutrition security.

Age was also an important determiner of being both under- and overweight. The younger the age, the higher the risk of being underweight. The older the age, the higher the risk of being overweight. Both studies in Uganda and India found a similar pattern $(19,20)$. A previous study had reviewed that childbearing years of women is one important period on the development of obesity among WRA with the long-term impact of body fat deposition which caused significant weight gain up to ten years later (5). In this study, most older women were having more than one child with the under-two children as their youngest children. A study in Kenya found that the average 31.5 years-old women were more likely to be overweight and obese than the average 28 years-old ones $(\mathrm{p}<.001)$. However, when they only included women having children under five, the older childbearing women were more likely to be underweight than younger ones (8). 
Table 1. Characteristics of Women in Reproductive Age (WRA) in Rural Ciampea Subdistrict, Bogor District, West Java Province $(N=575)$

\begin{tabular}{|c|c|}
\hline Characteristic & $n(\%)$ \\
\hline Age of $\mathbf{W R A}^{\mathbf{1}}$, years & $29(16-44)$ \\
\hline \multicolumn{2}{|l|}{ Education level } \\
\hline Low Education & $245(42.6)$ \\
\hline Middle Education & $182(31.7)$ \\
\hline High Education & $148(25.7)$ \\
\hline \multicolumn{2}{|l|}{ Working status $(\mathrm{n}=574)$} \\
\hline Working & $65(11.3)$ \\
\hline Family Planning & $514(89.4)$ \\
\hline \multicolumn{2}{|l|}{ Nutritional status } \\
\hline Underweight & $57(10.0)$ \\
\hline Overweight & $90(15.8)$ \\
\hline Obese & $194(34.2)$ \\
\hline \multicolumn{2}{|l|}{ Intake $^{1}$} \\
\hline Energy $(\mathrm{n}=573), \mathrm{kcal}$ & $1654.2(130-5625)$ \\
\hline Inadequate & $313(54.6)$ \\
\hline Excess & $23(4.0)$ \\
\hline Protein $(\mathrm{n}=574)$, gram & $53(2-526)$ \\
\hline Inadequate & $336(58.5)$ \\
\hline Excess & $82(14.3)$ \\
\hline \multicolumn{2}{|l|}{ Dietary diversity } \\
\hline Low (<3 Food Groups) & $136(23.7)$ \\
\hline Medium (3-4 Food Groups) & $342(59.5)$ \\
\hline High ( $>4$ Food Groups) & $97(16.9)$ \\
\hline \multicolumn{2}{|l|}{ Food security status } \\
\hline Food insecure severe hunger & $23(4.0)$ \\
\hline Food insecure moderate hunger & $54(9.4)$ \\
\hline Food insecure no hunger & $236(41.0)$ \\
\hline Food secure at risk & $130(22.6)$ \\
\hline Food secure & $132(23.0)$ \\
\hline
\end{tabular}


Table 2. Factors Associated with Underweight and Overweight among Women of Reproductive Age (WRA) In Rural Ciampea Sub-district, Bogor District, West Java Province ${ }^{1}$

\begin{tabular}{|c|c|c|c|}
\hline Variable & $\mathbf{N}$ & $\begin{array}{c}\text { Underweight } \\
\% \\
\end{array}$ & $\begin{array}{c}\text { Overweight } \\
\% \\
\end{array}$ \\
\hline \multicolumn{4}{|l|}{ Energy Intake (n = 566) } \\
\hline Inadequate $(<70 \%)$ & 310 & 8.4 & 50.6 \\
\hline Adequate $(70-130 \%)$ & 233 & 11.6 & 47.2 \\
\hline \multirow{2}{*}{ Excess $(>130 \%)$} & 23 & 13.0 & 69.6 \\
\hline & & $\mathrm{p}=0.417$ & $\mathrm{p}=0.117$ \\
\hline \multicolumn{4}{|l|}{ Protein Intake $(n=567)$} \\
\hline Inadequate $(<80 \%)$ & 331 & 9.7 & 49.0 \\
\hline Adequate $(80-120 \%)$ & 155 & 11.6 & 50.7 \\
\hline \multirow[t]{2}{*}{ Excess $(>120 \%)$} & 81 & 7.4 & 51.9 \\
\hline & & $\mathrm{p}=0.578$ & $\mathrm{p}=0.715$ \\
\hline \multicolumn{4}{|l|}{ Dietary Diversity $(n=568)$} \\
\hline Low ( $<3$ Food Groups) & 133 & 9.0 & 51.1 \\
\hline Medium (3-4 Food Groups) & 340 & 9.4 & 49.7 \\
\hline \multirow{2}{*}{ High ( $>4$ Food Groups) } & 95 & 13.7 & 49.5 \\
\hline & & $\mathrm{p}=0.428$ & $\mathrm{p}=0.956$ \\
\hline \multicolumn{4}{|l|}{ Nutritional Knowledge $(n=568)$} \\
\hline Low Knowledge & 317 & 9.5 & 46.4 \\
\hline \multirow[t]{2}{*}{ Good Knowledge } & 251 & 10.8 & 54.6 \\
\hline & & $\mathrm{p}=0.610$ & $\mathrm{p}=0.052$ \\
\hline \multicolumn{4}{|l|}{ Food Security $(n=568)$} \\
\hline Food insecure with hunger & 76 & 17.1 & 39.5 \\
\hline Food insecure no hunger & 235 & 7.2 & 52.3 \\
\hline Food secure at risk & 128 & 11.7 & 43.8 \\
\hline \multirow[t]{2}{*}{ Food secure } & 129 & 9.3 & 58.1 \\
\hline & & $\mathrm{p}=0.081$ & $\mathrm{p}=0.026^{* *}$ \\
\hline \multicolumn{4}{|l|}{ Education $(n=568)$} \\
\hline Low Education & 242 & 5.8 & 50.0 \\
\hline Middle Education & 181 & 12.2 & 49.7 \\
\hline \multirow[t]{2}{*}{ High Education } & 145 & 14.5 & 50.3 \\
\hline & & $\mathrm{p}=0.012^{* *}$ & $\mathrm{p}=0.994$ \\
\hline \multicolumn{4}{|l|}{ Working Status $(n=567)$} \\
\hline Not Working & 504 & 10.1 & 49.2 \\
\hline \multirow[t]{2}{*}{ Working } & 63 & 7.9 & 57.1 \\
\hline & & $\mathrm{p}=0.584$ & $p=0.235$ \\
\hline \multicolumn{4}{|l|}{ Wealth Index ${ }^{2}(n=568)$} \\
\hline Tertile 1 & 176 & 11.9 & 47.2 \\
\hline Tertile 2 & 227 & 10.6 & 48.0 \\
\hline \multirow[t]{2}{*}{ Tertile 3} & 165 & 7.3 & 55.8 \\
\hline & & $\mathrm{p}=0.338$ & $\mathrm{p}=0.211$ \\
\hline
\end{tabular}

${ }^{1}$ Statistical analysis was conducted independently for both under- and overweight (obese included as overweight) using chi-square analysis

${ }^{2}$ Wealth index is ranked as tertile. Lowest tertile (tertile 1) means having the lowest wealth index score or lowest socio-economic level.

**associated significantly $(\mathrm{p}<0.05)$ 
Table 3. Unadjusted and adjusted Odds-ratio (OR) of associated factors with underweight among women in reproductive age in rural Ciampea subdistrict, Bogor district, West Java province $(\mathrm{N}=\mathbf{5 7 5})$

\begin{tabular}{|c|c|c|c|c|c|c|c|c|}
\hline Variable & $\mathbf{n}$ & $\%$ & OR & CI $(95 \%)$ & p value & AdjOR & CI (95\%) & P value \\
\hline \multicolumn{9}{|l|}{ Food Security } \\
\hline Food insecure with hunger & 76 & 17.1 & 2.01 & $(0.87-4.67)$ & 0.104 & 3.95 & $(1.46-10.64)$ & $0.007^{* *}$ \\
\hline Food insecure no hunger & 235 & 7.2 & 0.76 & $(0.35-0.65)$ & 0.487 & 0.97 & $(0.42-2.2)$ & 0.944 \\
\hline Food secure at risk & 128 & 11.7 & 1.29 & $(0.58-2.89)$ & 0.528 & 1.24 & $(0.53-2.86)$ & 0.618 \\
\hline Food secure & 129 & 9.3 & 1 & & & 1 & & \\
\hline \multicolumn{9}{|l|}{ Education } \\
\hline Low Education & 242 & 5.8 & 0.36 & $(0.18-0.74)$ & 0.005 & 0.22 & $(0.10-0.52)$ & $0.000^{* *}$ \\
\hline Middle Education & 181 & 12.2 & 0.82 & $(0.43-1.55)$ & 0.537 & 0.18 & $(0.30-1.25)$ & 0.180 \\
\hline High Education & 145 & 14.5 & 1 & & & 1 & & \\
\hline \multicolumn{9}{|l|}{ Age group } \\
\hline 16-18 years & 6 & 33.3 & 10.29 & $(1.71-61.86)$ & 0.011 & 10.05 & $(1.48-68.22)$ & $0.018^{* *}$ \\
\hline $19-29$ years & 303 & 14.2 & 3.40 & $(1.75-6.61)$ & 0.000 & 3.34 & $(1.67-6.70)$ & $0.001^{* *}$ \\
\hline $30-49$ years & 259 & 4.6 & 1 & & & 1 & & \\
\hline \multicolumn{9}{|l|}{ Wealth Index } \\
\hline Tertile 1 & 176 & 11.9 & 1.73 & $(0.82-3.63)$ & 0.150 & 1.81 & $(0.78-4.20)$ & 0.167 \\
\hline Tertile 2 & 227 & 10.6 & 1.51 & $(0.73-3.11)$ & 0.267 & 1.44 & $(0.67-3.09)$ & 0.350 \\
\hline Tertile 3 & 165 & 7.3 & 1 & & & 1 & & \\
\hline
\end{tabular}

${ }^{* *}$ The most influential factors for underweight after adjustment | NegelkerkerR ${ }^{2}$ was 0.141 
Table 4. Unadjusted and adjusted Odds-ratio (OR) of associated factors with overweight and obese among women in reproductive age in rural Ciampea sub-district, Bogor district, West Java province $(N=575)$

\begin{tabular}{|c|c|c|c|c|c|c|c|c|}
\hline Variable & $\mathbf{n}$ & $\%$ & OR & CI $(95 \%)$ & p value & AdjOR & CI $(95 \%)$ & P value \\
\hline \multicolumn{9}{|l|}{ Energy Intake } \\
\hline Inadequate $(<70 \%)$ & 310 & 50.6 & 1.14 & $(0.81-1.61)$ & 0.428 & 1.23 & $(0.86-1.76)$ & 0.250 \\
\hline Excess $(>130 \%)$ & 23 & 69.6 & 2.56 & $(1.01-6.44)$ & 0.047 & 2.07 & $(0.80-5.35)$ & 0.134 \\
\hline Adequate (70-130\%) & 233 & 47.2 & 1 & & & 1 & & \\
\hline \multicolumn{9}{|l|}{ Nutritional Knowledge } \\
\hline Low Knowledge & 317 & 46.4 & 0.72 & $(0.51-1.00)$ & 0.052 & 0.75 & $(0.51-1.09)$ & 0.129 \\
\hline Good Knowledge & 251 & 54.6 & 1 & & & 1 & & \\
\hline \multicolumn{9}{|l|}{ Food Security } \\
\hline Food insecure with hunger & 76 & 39.5 & 0.47 & $(0.26-0.83)$ & 0.010 & 0.40 & $(0.21-0.77)$ & $0.006^{* *}$ \\
\hline Food insecure no hunger & 235 & 52.3 & 0.28 & $(0.51-1.22)$ & 0.288 & 0.74 & $(0.46-1.20)$ & 0.221 \\
\hline Food secure at risk & 128 & 43.8 & 0.56 & $(0.34-0.92)$ & 0.021 & 0.57 & $(0.34-1.00)$ & $0.036^{* *}$ \\
\hline Food secure & 129 & 58.1 & 1 & & & 1 & & \\
\hline \multicolumn{9}{|l|}{ Working Status } \\
\hline Not Working & 504 & 49.2 & 0.73 & $(0.43-1.23)$ & 0.236 & 0.91 & $(0.51-1.61)$ & 0.749 \\
\hline Working & 63 & 57.1 & 1 & & & 1 & & \\
\hline \multicolumn{9}{|l|}{ Wealth Index } \\
\hline Tertile 1 & 176 & 47.2 & 0.71 & $(0.46-1.08)$ & 0.113 & 0.98 & $(0.60-1.60)$ & 0.937 \\
\hline Tertile 2 & 227 & 48.0 & 0.73 & $(0.49-1.09)$ & 0.131 & 0.81 & $(0.53-1.25)$ & 0.340 \\
\hline Tertile 3 & 165 & 55.8 & 1 & & & 1 & & \\
\hline \multicolumn{9}{|l|}{ Age group } \\
\hline 16-18 years & 6 & 16.7 & 0.13 & $(0.01-1.16)$ & 0.069 & 0.14 & $(0.02-1.26)$ & 0.080 \\
\hline $19-29$ years & 303 & 42.2 & 0.49 & $(0.35-0.69)$ & 0.000 & 0.49 & $(0.34-0.70)$ & $0.000^{* *}$ \\
\hline $30-49$ years & 259 & & 1 & & & 1 & & \\
\hline \multicolumn{9}{|l|}{ Education } \\
\hline Low Education & 242 & 50.0 & 0.99 & $(0.65-1.49)$ & 0.948 & 1.20 & $(0.73-1.97)$ & 0.462 \\
\hline Middle Education & 181 & 49.7 & 0.97 & $(0.63-1.51)$ & 0.911 & 1.13 & $(0.70-1.83)$ & 0.626 \\
\hline High Education & 145 & 50.3 & 1 & & & 1 & & \\
\hline
\end{tabular}

${ }^{* *}$ The most influential factors for overweight after adjustment $\mid$ NegelkerkerR $^{2}$ was 0.08 
We highlighted some extraordinary findings in this study. First, on the association between education level and underweight. Our analysis found that most women with the lowest education level (elementary school) were 30-49 years-old. This might explain why women with lower education were less prevalent of being underweight but more prevalent of being overweight. Second, women with higher nutrition knowledge tended to be more overweight. More than half of overweight WRA had good nutrition knowledge, however, it was not a guarantee that they applied it into practice. Even though there was no clear association between nutritional knowledge and nutritional status, we found that the higher the nutritional knowledge, the higher the energy intake of this WRA $(\mathrm{p}=.024)$. Our further analysis also found that the wealthier the WRA, the higher the nutritional knowledge score $(\mathrm{p}<.001)$. It signified that the wealthier status of WRA was related to the occurrence of overweight. In addition, around half of the WRA, had inadequate intake of both energy and protein while a few also had excess intakes. This indicated how poor diet quality is.

The majority of socio-economic characteristics in this study were 29 years old of WRA (median), living in rural areas in crowded West Java area, in general with evenly distributed wealth status with more of them were working. Data also indicated that most of them were bluecollar worker and having a middle educational level (maximally junior high graduates). A study in Eastern Uganda showed slightly different results from our findings, the dominancy of WRA with the overweight and obese conditions were located in the peri-urban area rather than in rural area (19). Meanwhile, a study in India showed that the increasing number of overweight and obesity among WRA in rural areas were due to improved socioeconomic level as well as poor quality of the diet (20).

This study's systematic sampling procedure, randomization, and adequate sample size were strengths of this study, although there were some limitations. On gathering the dietary intake data, we used a single 24-hour dietary recall which might lead to under- or over-estimation of the intakes. However, we had additional information about whether the consumption was the participants' daily consumption, and more than $90 \%$ was 'yes'. Unfortunately, there was no respondents' physical activity as it took important rules explaining the overnutrition condition literally. We assumed approximately similar physical activity because most of the WRA were mothers of under-two years children who exposed to the same environment.

\section{Conclusion}

This study has shown that food security status and age were the two strongest predictors of underweight and overweight status in this population. Thus, the food security condition might be a more modifiable risk. Accordingly, ensuring the availability and affordability of nutritious food with proper nutrition education to rural communities might be worthwhile to improve the present conditions. Discovering potential localbased food ingredients to fulfil WRA's nutrients requirement at an affordable price can be an alternative in ensuring food security and good diet quality of the rural population in Indonesia.

\section{Acknowledgments}

With funding support from the Ministry of Education through SEAMEO SEAMOLEC, we would like to acknowledge people who were involved 
in the survey: drg. Paulus Daniel Sahanggamu, M.Sc, Indriya Laras Pramesthi M.Sc, Purnawati Hustina Rachman, M.Sc, and Devita Kusuma Rahingtyas, SP, M.Gz. Our gratitude to Ida Ayu Devi Qirani, S.Gz. who took part in manuscript finalization as well as Elek Pafka, $\mathrm{PhD}$ from the University of Melbourne to proofread the paper. We also thank all our enumerators, respondents, Posyandu's cadres, as well as the local authorities for all the efforts that had been made for this study.

\section{References}

1. Bezerra, I.N. and Sichieri, R. Household Food Diversity and Nutritional Status among Adults in Brazil. International Journal of Behavioral Nutrition and Physical Activity. 2011;8;22.

2. Chaparro, Camila. Household Food Insecurity and Nutritional Status of Women of Reproductive Age and Children Under 5 Years of Age in Five Departments of the Western Highlands of Guatemala: An Analysis of Data from the National MaternalInfant Health Survey 2008-09 of Guatemala. Washington DC: FHI 360/FANTA-2 Bridge; 2012.

3. Food and Agriculture Organization (FAO). Guidelines for Measuring Household and Individual Dietary Diversity. Nutrition and Consumer Protection Division, Food and Agriculture Organization of the United Nations. Rome (Italy): FAO; 2010. ISBN 978-92-5-106749-9

4. Gulliford, M.; Mahabir, D. and Rocke, B. Food Insecurity, Food Choices, and Body Mass Index In Adults: Nutrition Transition In Trinidad And Tobago. International Journal of Epidemiology.2003;32(4):508-516.

5. Gunderson, Erika P. Childbearing and Obesity In Women: Weight Before,
During, and After Pregnancy. Obstetrics and Gynecology Clinics of North America. 2009;36(2);317-ix. doi: 10.1016/j.ogc.2009.04.001.

6. Jones-Smith, J.C., et al. Is the Burden of Overweight Shifting to the Poor Across The Globe? Time Trends among Women in 39 Low- and Middle-Income Countries (19912008). Int $\mathrm{J}$ Obes (Lond). 2012;36(8);1114-1120.

7. Komakech, A.G. L. Factors Influencing the Nutritional Status of Women of Reproductive Age in Erute Internally Displaced Persons' Camp_Lira District [thesis]. Faculty of Agriculture, Department of Food Science and Technology, Makerere University, Uganda; 2010.

8. Kotut, J. et al. Protein-Energy Malnutrition among Women of Child Bearing Age in Semi-Arid Areas of Keiyo District, Kenya. Advances in Life Science and Technology. 2014;24;80-91. ISSN 2224-7181 (Paper) ISSN 2225-062X (Online). www.iiste.org.

9. Larson, N. and Story, M. Food Insecurity and Weight Status among US Children and Families: A Review of the Literature. American Journal of Preventive Medicine. 2011;40(2);166-173.

10. Ministry of Health (MoH). Riset Kesehatan Dasar (Riskesdas) 2013. "Basic Health Research 2013". Ministry of Health of Indonesia:Jakarta; 2013.

11. Ministry ofHealth (MoH). Buku Studi Diet Total: Survei Konsumsi Makanan Individu Indonesia 2014. "Total Diet Study Book: Individual Food Consumption Survey of Indonesia 2014". Jakarta: Publishing Institution of Badan Litbangkes: Jakarta; 2014a.

12. Ministry of Health $(\mathrm{MoH})$. Pedoman Gizi Seimbang. Balance Diet 
Guideline. Ministry of Health of Indonesia: Jakarta; 2014b.

13. Rotimi, C. et al. The Distribution and Mortality Impact of Chronic Energy Deficiency among Adult Nigerian Men and Women. European Journal of Clinical Nutrition. 1999;53;734-739.

14. United Nations (UN). Sustainable Development Goals (SDGs). 2016. Available

at: http://www.un.org/sustainabledevelop ment/sustainable-development-goals/

15. World Health Organization (WHO). BMI Classification. WHO Global Database on Body Mass Index. 2014. Available at : http://apps.who.int/bmi/index.jsp?intr oPage=intro 3.html

16. World Bank. World Bank List of Economies (January 2015). 2015. Available http://go.worldbank.org/47F97HK2P $\underline{0}$

17. Xinxo, S., et al. Association between Maternal Nutritional Status of Pre Pregnancy, Gestational Weight Gain and Preterm Birth. Journal of the Academy of Medical Sciences of Bosnia and Herzegovina. 2013;25(1);6-8.

18. World Health Organization (WHO). Obesity and inequities: Guidance for addressing inequities in overweight and obesity. Copenhagen (Denmark): WHO Press; 2014.

19. Kirunda, B.E., Fadnes, L.T., Wamani, H. et al. Population-based survey of overweight and obesity and the associated factors in peri-urban and rural Eastern Uganda. BMC Public Health. 2015;15;1168.

20. Meshram, I., Balakrishna, N., Sreeramakrishna, K., Rao, K., et al. Trends in nutritional status and nutrient intakes and correlates of overweight/obesity among rural adult women $(\geq 18-60$ years) in India: National Nutrition Monitoring Bureau
(NNMB) national surveys. Public Health Nutrition. 2016;19(5);767-776. 